\title{
Hubungan Rasio Neutrofil - Limfosit Dengan Skor Sequential Organ Failure Assesment Pada Pasien Sepsis Di Intensive Care Unit RSUP Dr. M. Djamil Padang
}

\author{
Aufa Ummaimah Epiloksa, Efrida², Zulfadli Syahrul ${ }^{3}$
}

\begin{abstract}
Abstrak
Sepsis adalah disfungsi organ yang mengancam jiwa, disebabkan oleh disregulasi respons imun akibat infeksi. Respons fisiologis sistem imun terhadap infeksi adalah dengan peningkatan jumlah neutrofil dan penurunan jumlah limfosit atau peningkatan Rasio Neutrofil-Limfosit (RNL). Kerusakan dan kegagalan fungsi organ dapat dimonitor dengan skor Sequential Organ Failure Assesment (SOFA). Tujuan: Mengetahui korelasi antara RNL dengan skor SOFA pada pasien sepsis di Intensive Care Unit (ICU) RSUP Dr M Djamil Padang. Metode: Penelitian ini adalah studi analitik dengan rancangan potong lintang menggunakan data rekam medis pasien sepsis di ICU RSUP Dr M Djamil Padang tahun 2018. Data RNL dan skor SOFA diambil saat hari pertama dirawat di ICU. Analisis univariat disajikan dalam bentuk tabel distribusi frekuensi dan data bivariat diuji dengan uji korelasi Pearson. Korelasi dinyatakan bermakna jika $p<0,05$. Hasil: Uji univariat didapatkan pasien terbanyak adalah laki -laki $(77 \%)$, rerata usia adalah 50,2 tahun, tipe penyakit dasar terbanyak adalah non-surgical (70\%), rerata RNL adalah $16,5 \pm 10,6$, dan rerata skor SOFA adalah 7,23 $\pm 3,44$. Analisis bivariat meunjukan korelasi positif sangat kuat antara RNL dengan skor SOFA $(r=0,982$ dan $p<0,05)$. Simpulan: Terdapat hubungan antara RNL dengan skor SOFA pada pasien sepsis di ICU RSUP Dr. M. Djamil Padang.
\end{abstract}

Kata kunci: rasio neutrofil-limfosit, sofa, sepsis

\begin{abstract}
Sepsis is a life-threatening organ dysfunction, caused by dysregulation of the immune response because of infection. The physiological response of the immune system to infection is by increasing the number of neutrophils and decreasing the number of lymphocytes or increasing the Ratio of Neutrophils to Lymphocytes (RNL). Organ damage and malfunction can be monitoredwith Sequential Organ Failure Assessment (SOFA) scores. Objectives: To determined the correlation between RNL and SOFA scores in sepsis patients in Intensive Care Unit (ICU) RSUP Dr M Djamil Padang. Methods: This was an analytic study with cross sectional design by using medical records of sepsis patients in ICU Dr. M. Djamil Padang in 2018. RNL data and SOFA scores were taken on the first day being treated at the ICU. Univariate analysis was presented in the form of a frequency distribution table and bivariate data are tested with the Pearson correlation test. Correlation was significant if $p<0.05$. Results: Univariate results showed that most patients were male (77\%), the mean age was 50.2 years old, the type of base disease was non-surgical (70\%), the mean RNL was $16.5 \pm 10.6$, and the average SOFA score is $7.23 \pm 3.44$. Bivariate analysis showed a very strong positive correlation between RNL and SOFA scores ( $r=0.982$ and $p<0.05)$. Conclusion: There is relationship between RNL andSOFA scores in sepsis patients in ICU RSUP Dr. M. Djamil Padang.
\end{abstract}

Keywords : Ratio of Neutrophil to lymphocyte, SOFA, Sepsis

Affiliasi penulis: 1. Prodi Pendidikan Dokter, Fakultas Kedokteran, Universitas Andalas, Padang, Indonesia. 2. Bagian Patologi Klinik, Fakultas Kedokteran, Universitas Andalas, Padang, Indonesia.
3. Bagian Anestesi, Fakultas Kedokteran, Universitas Andalas, Padang, Indonesia.

Korespondensi: Efrida, Email: efridasppk@yahoo.com Telp: 082170206650 


\section{PENDAHULUAN}

Sepsis adalah kondisi klinis akut dan serius yang muncul karena adanya mikroorganisme patogen dalam aliran darah. Kejadian sepsis terus meningkat setiap tahunnya. ${ }^{1}$ Berdasarkan Surviving Sepsis Campaign, angka mortalitas pasien sepsis di Intensive Care Unit (ICU) Amerika Serikat $28,3 \%$ dan Eropa $41,1 \%$, sedangkan angka mortalitas pasien sepsis berat di 150 ICU di 16 negara Asia adalah 44,5\%. ${ }^{2}$ Penelitian yang dilakukan di ruangan ICU RSUP Prof $\mathrm{Dr}$ RD Kandou Manado pada tahun 2016 terdapat 82,2\% pasien sepsis, $11,4 \%$ pasien sepsis berat, dan $5,7 \%$ syok sepsis. ${ }^{1}$

Jumlah kejadian sepsis di RSUP Dr M Djamil Padang meningkat sebesar 50\%. Pada tahun 2010 adalah 351 pasien, 2011 adalah 512 pasien, 2012 adalah 757 pasien, dan 2013 adalah 734 pasien. Jumlah kejadian sepsis pada tahun 2016 sebanyak 995 pasien, dan bulan Januari sampai Desember 2017 sebanyak 718 pasien. ${ }^{3}$

Sepsis adalah disfungsi organ yang mengancam jiwa yang disebabkan oleh disregulasi respons imun akibat infeksi serta menjadi kondisi umum di ICU yang berhubungan dengan mortalitas dan morbiditas. ${ }^{4}$ Mortalitas dan morbiditas di ICU ditentukan oleh perkembangan kegagalan fungsi organ yang terjadi. Kerusakan dan kegagalan fungsi organ tersebut dapat dimonitor antara lain dengan menggunakan skor Sequential Organ Failure Assesment (SOFA). ${ }^{5}$

Skor SOFA merupakan salah satu sistem skoring yang dapat memprediksi outcome pasien di ICU yang manilai fungsi pernapasan, pemeriksaan koagulasi, fungsi hepar, fungsi jantung, pemeriksaan hematologi, dan sistem saraf pusat yang berhubungan dengan gagal organ dan mortalitas. ${ }^{6}$ Jumlah skor SOFA rata-rata pada 48 jam pertama merupakan indikator prognosis yang cukup baik untuk memprediksi keadaan pasien. Tujuan utama menilai skor SOFA adalah untuk menggambarkan komplikasi yang terjadi pada pasien. ${ }^{5}$

Berdasarkan penelitian sebelumnya leukosit berperan penting dalam respons inflamasi sistemik (infeksi berat, trauma, dan syok). ${ }^{5}$ Respons imun terhadap endotoksin telah ditemukan dengan peningkatan jumlah neutrofil dan penurunan jumlah limfosit. Akibat peningkatan jumlah neutrofil serta penurunan jumlah limfosit akan meningkatkan rasio neutrofil - limfosit (RNL). ${ }^{5} \mathrm{RNL}$ adalah perbandingan jumlah neutrofil absolut dengan limfosit absolut. Jumlah neutrofil absolut dan limfosit absolut dapat diketahui melalui pemeriksaan yang rutin dilakukan di rumah sakit yaitu pemeriksaan hitung jenis leukosit dan jumlah leukosit.7,8

Pada penelitian respons imunitas terhadap proses inflamasi terjadi penurunan jumlah limfosit sekitar $85 \%$ dan peningkatan neutrofil sekitar $30 \%$. Hal ini disebabkan karena perubahan dinamika dan regulasi apoptosis pada keadaan inflamasi sistemik. Penundaan proses apoptosis neutrofil akan berakibat pemanjangan fungsi neutrofil dalam proses inflamasi. Sebaliknya, peningkatan apoptosis limfosit akan berakibat pada penurunan efektor inflamasi dan juga imunosupresi. ${ }^{9}$

Metabolik toksik yang dilepaskan neutrofil teraktifasi dan sitokin inflamasi akan merusak jaringan serta menyebabkan gangguan fungsi organ. Kerusakan dan kegagalan fungsi organ yang terjadi dapat dimonitor menggunakan skor SOFA. ${ }^{5}$

Studi yang dilakukan di Rumah Sakit Dr. Hasan Sadikin Bandung tahun 2013 tentang hubungan antara RNL dan skor SOFA pada pasien yang dirawat di ruang ICU membuktikan bahwa terdapat hubungan antara keadaan inflamasi sistemik yang ditandai dengan peningkatan RNL dan kegagalan fungsi organ yang ditandai dengan peningkatan skor SOFA. Data penelitian tersebut dianalisis menggunakan uji korelasi Person $(r=0,63 ; p<0,05) .{ }^{5}$

Penelitan tentang hubungan RNL dengan skor SOFA belum banyak dilakukan sehingga dibutuhkan penelitan lain mengenai RNL dengan skor SOFA untuk melanjutkan penelitian sebelumnya. Penelitian mengenai RNL dan skor SOFA belum pernah dilakukan di RSUP Dr M Djamil Padang. Apabila penelitian ini menunjukan hasil yang berhubungan di RSUP $\operatorname{Dr} M$ Djamil Padang diharapkan dapat menjadi suatu acuan untuk mengambil kebijakan tatalaksana pada pasien sepsis dengan jumlah RNL yang meningkat sehingga prognosis pasien lebih baik.

Berdasarkan latar belakang diatas maka penulis tertarik meneliti Hubungan Rasio Neutrofil-Limfosit dengan Skor Sequential Organ Failure Assesment (SOFA) pada pasien sepsis yang dirawat di Intensive Care Unit (ICU) RSUP Dr M Djamil Padang. 


\section{METODE}

Jenis penelitian yang digunakan adalah analitik observasional dengan pendekatan cross sectional retrospektif dengan menggunakan data rekam medik di RSUPdr. M. Djamil Padang. Variabel independennya adalah rasio neutrofil-limfosit dan variabel dependennya adalah skor SOFA. Penelitian dilakukan dari April - Juni 2019 di bagian rekam medik RSUP Dr. M. Djamil Padang.

Populasi penelitian ini adalah seluruh data rekam medik pasien sepsis yang dirawat di ICURSUP Dr. M. Djamil Padang periode 2018.

Sampel penelitian yang dipilih adalah data rekam medik yang memenuhi kriteria Inklusi dan ekslusi. Kriteria inklusi: Rekam medis pasien sepsis dengan data lengkap. Kriteria eksklusi: Rekam medik pasien sepsis dengan riwayat kemoterapi dan rekam medik pasien sepsis dengan keganasa sel darah.

Jumlah sampel yang dibutuhkan adalah 30 sampel. Teknik pengambilan sampel yang digunakan adalah konsekutif, yaitu semua sampel yang memenuhi kriteria dimasukkan ke dalam penelitian hingga sampel minimal terpenuhi.

Data dianalisis secara statistik berdasarkan variabel yang dinilai menggunakan system komputerisasi yaitu analisis univariat dan bivariat. Analisis univariat dilakukan untuk mengetahui gambaran dari masing-masing variabel yang diteliti. Analisis bivariat dilakukan untuk mencari korelasi antara dua variabel, yaitu rasio neutrofil-limfosit dan skor SOFA pada pasien sepsis di RSUP Dr. M. Djamil Padang. Data dianalisis dengan uji korelasi Pearson.Korelasi dinyatakan bermakna jika didapatkan nilai $p<0,05$.

\section{HASIL}

Penelitian ini menggunakan rekam medis pasien sepsis di ICU RSUP Dr. M. Djamil Padang tahun 2018 yang memenuhi kriteria inklusi dan eksklusi. Jumlah sampel yang digunakan adalah 30 sampel.
Tabel 1. Karakteristik dasar pasien

\begin{tabular}{lccc}
\hline Karakteristik & $\mathbf{f}$ & $\%$ & Rerata (SD) \\
\hline JenisKelamin & & & \\
Laki-Laki & 23 & 76.7 & \\
Perempuan & 7 & 23.3 & \\
Umur (tahun) & & & $50,2(20,8)$ \\
PenyakitDasar & & & \\
Surgical & 9 & 30 & \\
Non-surgical & 21 & 70 & \\
\hline
\end{tabular}

Pada tabel diatas dapat dilihat bahwa penedita sepsis lebih banyak laki - laki (76,7\%) dibandingkan perempuan $(23,3 \%)$. Rerata umur subjek penelitian adalah 50,2 $\pm 20,8$ tahun dengan rentang umur 12-91 tahun. Penelitian ini juga mendapatkan penyakit dasar subjek penelitian terbanyak berasal dari non - surgical $(70 \%)$.

Tabel 2. Rasio neutrofil-limfosit dan skor SOFA

\begin{tabular}{ll}
\hline Variabel & Rerata (SD) \\
\hline RasioNeutrofil-Limfosit & $16.5(10.61)$ \\
Skor SOFA & $7.23(3.44)$ \\
\hline
\end{tabular}

Rerata rasio neutrofil-limfosit pasien sepsis yang dirawat di ICU adalah 16,5 dengan nilaiter kecil 6,00 dan tertinggi 48,00. Rerata skor SOFA pada pasien sepsis di ICU adalah 7,23 dengan nilai terkecil adalah 3,00 dan tertinggi 17,00 .

Uji normalitas dengan Saphiro-Wilk terhadap rasio neutrofil-limfosit dan skor SOFA memperlihatkan bahwa distribusi data tidak normal. Selanjutnya dilakukan transformasi log pada rasio neutrofil - limfosit dan skor SOFA kemudian dilakukan kembali uji normalitas, didapatkan nilai $p=0,116$ untuk rasio neutrofil - limfoait dan $p=0,535$ untuk skor SOFA.

Uji korelasi Pearson terhadap rasio neutrofil limfosit dengan skor SOFA pada pasien sepsis di ICU RSUP Dr. M. Djamil padang didapatkan korelasi positif sangat kuat $(r=0,986)$, hasil ini bermakna secara ststistik $(p<0,005)$. Analisis ini menunjukkan rasio neutrofil - limfosit yang meningkat diikuti dengan peningkatan skor SOFA (Gambar 1). 


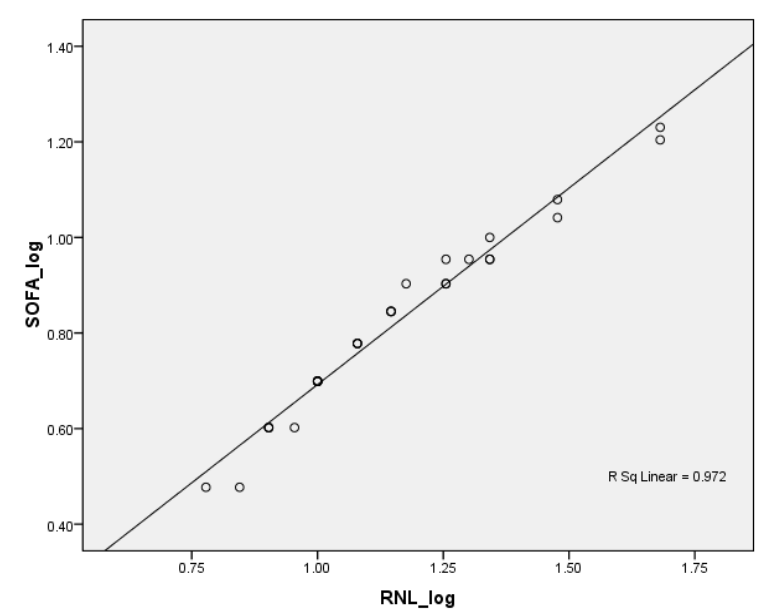

Gambar 1. Kurva korelasi rasio neutrofil-limfosit dengan Skor SOFA

\section{PEMBAHASAN}

Penelitian ini mendapatkan jenis kelamin laki laki $(76,7 \%)$ lebih banyak dari jenis kelamin perempuan $(23,3 \%)$, sesuai dengan penelitian yang dilakukan pada tahun 2014 di Cina tentang gambaran dan prognosis sepsis berat dan syok septik di ICU mengatakan bahwa $60,4 \%$ subjek penelitian adalah laki - laki. ${ }^{10}$ Hal ini dipengaruhi oleh hormon estrogen pada perempuan yang memiliki efek protektif terhadap terjadinya infeksi, sepsis dan trauma. Hormon estrogen berpengaruh dalam peningkatan sistem imun melalui peningkatan produksi IL-4 dan IL-10 sehingga antibodi meningkat. ${ }^{11}$

Hasil penelitian ini menunjukkan rerata umur subjek penelitian adalah 50,2 tahun dengan rentang umur 12 - 91 tahun. Hal ini sesuai dengan penelitian di Amerika Serikat tahun 2001 mendapatkan hasil yang mendekati hasil penelitian ini yaitu kejadian sepsis secara umum lebih banyak terjadi pada rentang umur 20 - 85 tahun. ${ }^{12}$ Hal ini terjadi karena tanggapan makrofag dan sistem imun bawaan lain seperti sel mukosa, sel kulit, silia, dan pembentukan protein fase akut mengalami penurunan serta penurunan jumlah limfosit T akibat reabsorbsi timus. ${ }^{13}$

Rerata rasio neutrofil-limfosit pada penelitian ini adalah 16.5, angka tersebut lebih tinggi dari nilai normal RNL yaitu $<4,67$. Peningkatan RNL terjadi karena adanya mekanisme yang bertanggung jawab atas proses limfositopenia pada sepsis yang melibatkan proses marginalisasi dan redistribusi limfosit dalam sistem limfatik serta percepatan proses apoptosis. ${ }^{9}$ Proses apoptosis tersebut terjadi ketika bakteri atau produk merangsang makrofag untuk melepaskan zat proapoptosis, seperti TNF- $\alpha$, nitrit oksida (NO) dan glukokortikoid. Kondisi ini kemudian akan menekan produksi limfosit. ${ }^{14}$

Penelitian ini mendapatkan korelasi positif sangat kuatan tara rasio neutrofil-limfosit dengan skor SOFA. Hasil ini sesuai dengan penelitian di Bandung tahun 2013 yang juga meneliti korelasi rasio neutrofil limfosit dengan skor SOFA pada 78 pasien sepsis yang dirawat di ICU Rumah Sakir Dr Hasan Sadikin Bandung. Penelitian ini mengatakan terdapat korelasi antara kedua parameter tersebut $(r=0,6, p<0,05) .{ }^{5}$

Penelitian diatas menunjukan bahwa pada inflamasi sistemik berat seperti sepsis, sistem imunitas tubuh berespons dengan peningkatan rasio neutrofillimfosit. ${ }^{15}$ Peningkatan RNL terjadi karena adanya stimulasi langsung maupun tidak langsung dari sumsum tulang yang menyebabkan jumlah neutrofil dalam darah meningkat. ${ }^{16}$ Peningkatan neutrofil tersebut disebabkan oleh sitokin proinflamasi seperti IL-6, IL-1 dan TNF- $\alpha$ yang diproduks ioleh makrofag dan penurunan jumlah limfosit yang disebabkan oleh peningkatan sekresi hormon glukokortikoid yang menekan produksi limfosit. ${ }^{13}$

Sitokin pro-inflamasi (IL-1, IL-6, dan TNF- $\alpha$ ) akan menstimulasi polymorphonuclear neutrophilic leukocyte (PMN) melekat ke sel endotel pembuluh darah. ${ }^{17}$ Leukosit melepaskan protease, oksidan, prostaglandin serta leukotrin yang akan menyebabkan kerusakan permukaan endotel sehingga factor jaringan dilepaskan. ${ }^{18}$ Faktor jaringan tersebut mencetuskan proses koagulasi melalui pelepasan trombin. Pelepasan thrombin akan menyebabkan perubahan fibrinogen menjadi fibrin sehingga terbentuk bekuan fibrin. ${ }^{19}$ Pada keadaan sepsis, proses fibrinlisis terganggu karena tingginya kadar plasminogen activator inhibitor-1 (PAI1) yang mencegah perubahan plasminogen menjadi plasmin, sehingga penghancuran fibrin berkurang, sedangkan aktivasi koagulasi terus berjalan menyebabkan penumpukan bekuan fibrin. ${ }^{20}$ Bekuan fibrin yang terbentuk akan menuju sirkulasi dan pembuluh darah kecil, sehingga suplai oksigen kejaringan dan organ tubuht erganggu. Akibatnya terjadi iskemia jaringan dan disfungi organ seperti organ pernapasan, kardiovaskuler, ginjal dan heparr serta terjadi penurunan kesadaran. ${ }^{11}$ 
Hasil yang didapatkan pada penelitian ini semakin menguatkan landasan teori dan hasil penelitian lain bahwa terdapat korelasi rasio neutrofil limfosit dengan kondisi klinis pasien sepsis yang dapat dinilai dengan skor SOFA. ${ }^{7}$

\section{SIMPULAN}

Terdapat korelasi antara rasio neutrophil-limfosit dengan skor SOFA pada pasien yang dirawat di ICU.

\section{UCAPAN TERIMA KASIH}

Terima kasih kepada semua pihak yang telah membantu dalam pelaksanaan penelitian. Kepada Direktur Umum RSUP Dr M Djamil Padang yang telah memberikan izin melaksanakan penelitian dan kepada staf bagian rekam medik yang telah membantu penulis dalam melaksanakan penelitian.

\section{DAFTAR PUSTAKA}

1. Tambajong, Rheza N, Lalenoh DC, Kumaat L. Profil penderita sepsis Di ICU RSUP Prof. Dr. R. D. Kandou Manado Periode Desember 2014 November 2015. Jurnal e- Clinic (eCL). 2016;4(1):452-7.

2. Dellinger RP, Levy MM, Rhodes A, Annane D, Gerlach H, Opal SM, et al. Surviving sepsis campaign: international guidelines for management of severe sepsis and septic shock, 2012. Journal of Critical Care Medicine. 2013 Feb;41:580-637.

3. Instalasi Rekam Medik RSUP Dr. M. Djamil Padang. Data rekam medik sepsis tahun 2017 bagian rawat jalan. Padang: RSUP Dr. M. Djamil;2017.

4. Keputusan menteri kesehatan republik indonesia nomor HK.01.07/MENKES/342/2017 tentang pedoman nasional pelayanan kedokteran tata laksana sepsis. Jakarta: Kemenkes RI; 2017.

5. Nugroho A, Suwarman, Nawawi AM. Hubungan antara rasio neutrofil-limfosit dan skor sequencial organ failure assesment pada pasien yang dirawat di ruang intensive care unit. Jurnal Anestesi Perioperatif. 2013;1(3):18996.

6. Jones AE, Trzeciak S, Kline JA. The sequential organ failure assessment score for predicting outcome in patients with severe sepsis and evidence of hypoperfusion at the time of emergency departement presentation. Journal of Critical Care Medicine. 2009; 37(5):1649-54.

7. Chairlan, Lestari E.Hematologi. Dalam: Mahode AA, editor. Pedoman teknik dasar untuk laboratorium kesehatan. Edisi ke-2. Jakarta: EGC.2011.hlm.310.

8. Irmayanti, Nurulita A, Sennang N. Rasio neutrofil limfosit pada demam berdarah dengue. Majalah Patologi Klinik Indonesia dan Laboratorium Medik. 2017;23(3):234-9.

9. Jager CPC. Lymphocytopenia and neutrophillymphocyte count ratio predict bacteremia better than conventional infection markers in an emergence unit. Journal of Critical Care Medicine. 2010;14(5):1-8.

10. Zhou J, Qian C, Zhao M, Yu X, Kang Y, Ma X, et al. Epidemiology and outcome of severe sepsis and septic shock in intensive care units in mainland China. Journal of PloS One. 2014;9(9):1-8.

11. Angele MK, Pratscke S, Hubbard WJ, Chaudry IH. Gender differences in sepsis cardiovascular and immunological aspects. Journal of Virulence. 2014 Jan 1;5(1):12-9.

12. Angus DC, Linde-Zwirble WT, Lidicker J, Clermont G, Carcillo J, Pinsky MR. Epidemiology of severe sepsis in the United States: analysis of incidence, outcome, and associated costs of care. Journal of Critical Care Medicine. 2001;29(7):1-8.

13. Zhang $H$, Wang $X$, Zhang $Q$, Xia $Y$, Liu D. Comparison of procalcitonin and high-sensitivity creactive protein for the diagnosis of sepsis and septic shock in the oldest old patients. BMC Geriatrics. 2017;17(1):1-6.

14. Parrino, Hotchkiss, Bray M. Prevention of immune cell apoptosis as potential therapeutic strategy: lymphocyte apoptosis in sepsis. Journal of Emerging Infectious Diseases, 2007;13(2):191-8.

15. Jacqueline $P$, Bryony $C$. An overview of the immune system. Lancet. 2001;357:1777-90.

16. Liu X, Shen $Y$, Wang $H$, Ge Q, Fei A, Pan S. Prognostic significance of neutrophil-to-lymphocyte ratio in patients with sepsis: a prospective observational study. Mediators of Inflammation. 2016:1-8.

17. Zahorec R. Ratio of neutrophil to lymphocite counts and simple parameter of systemic Inflamation and 
stress in critically III. Bratisl Lek Listy. 2009; 102(1): 5-14.

18. Guntur A. Sepsis. Dalam: Setiati S, Alwi I, Sudoyo AW, Setiyohadi B, Simadibrata M. Editor . Buku Ajar IImu Penyakit Dalam. Edisi ke-6. Jakarta: Internalpublishing; 2014.hlm.1862-5.

19. Szedejesi J, Almasy E, Lazar A, Hutanu A, Badea I,
Georgescu A. An evaluation of serum procalcitonin and $\mathrm{C}$ - reactive protein levels as diagnostic and prognastic biomarkers of severe sepsis. Journal of Critical Care Medicine. 2015;1(4):147-53.

20. Irwan I, Gaus S, Arif SK. Korelasi Skor SOFA dengan kadar laktat darah dan C- reactive protein pada pasien sepsis. Jurnal Kedokteran Terapi Intensif. 2012; 2(4):1-8. 